\title{
Laws and regulations associated with ownership of human biological material in South Africa
}

\author{
K P Mahesh, BSc Hons, MScMed \\ Medical scientist, Academic co-ordinator, University of Pretoria, South Africa
}

Corresponding author:KP Mahesh (kishen411@hotmail.com)

\begin{abstract}
Ownership with regard to human biological material (HBM) is addressed to some extent within South African law, specifically in chapter eight of the National Health Act (NHA) and its associated regulations. However, members of the legal fraternity struggle to conceptualise ownership of such materials without objectifying a person or people and risking reducing such individuals to a state of property. This then infers a reduction in human dignity by rendering one-self or parts of that same self as a commodity. The complexity of the issue raises much debate both legally as well as ethically.
\end{abstract}

SAfr J BL 2015:8(1)11-18. DOI:10.7196/SAJBL.354

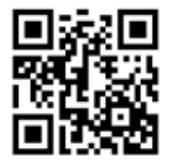

South Africa's laws with regard to human biological material (HBM), specific to that of genetic research, have over the years proved to be a fairly prominent topic of discussion. This in turn has led to the drafting and now enacted legislation, chapter eight of the National Health Act (NHA). However, several questions have arisen, post promulgation, with regard to the issue of ownership of such biological materials. One of the major issues identified is lack of a clear enough definition of HBM. Various acts and regulations related to research and the diagnostic use of HBM define such materials in various ways. The lack of a universal definition therefore creates room in the legislature from which exploitative acts may arise. This article aims to highlight some of these gaps as well as put forward recommendations for a universal definition to be used by all involved with HBM.

\section{Defining ownership}

The description of ownership stems mainly from South African common-law. ${ }^{[1]}$ Ownership has been defined in various decisions as 'the most complete real right which gives the owner the most complete and absolute entitlement to a thing. Even so, it is a right which can be limited by objective law and by the rights of others'. A 'thing' is defined 'in terms of characteristics, as a corporeal or tangible object external to persons and which is, as an independent entity, subject to judicial control by a legal subject, to whom it is useful and of value.[1]

HBM such as genetic material (DNA and RNA) in this sense is reflective of what a 'thing' would be. Genetic material meets the criteria that are used as definable characteristics of a thing. It is corporeal, in belonging to a physical body and tangible, in being material that can be made visible, of definite substance and can be quantified. ${ }^{[1]}$

According to Regulation 180 (S26) in chapter eight of the NHA, an exclusive right in human tissue is acquired by any person who obtains the human tissue, subject to informed consent and the provisions and restrictions of the NHA or any other law. ${ }^{[2]}$ Such regulation pertaining to biological material capable of yielding genetic material within the NHA portrays a sense of exclusive property rights from donor to donee, the latter being a researcher, doctor, or research institute, for example. ${ }^{[3]}$
This transfer of exclusive rights therefore implies that when elements of the human body are separated from a person, the material gained loses its identity and is to be considered a biological material that no longer has relatedness to the person who has donated it. This may be true for biological material removed from a person when the sample is coded or made anonymous but the genetic information within those materials are capable of identification. For example, if a population group under genetic investigation is found to hold in their genomic sequence a rare variant or Single Nucleotide Polymorphism (SNP) that specifically clusters within that group, it then acts as an identifiable marker to that population. Depending on the type of genetic association predicted to be linked to that SNP, a population may become vulnerable to further genetic exploitation and cultural intrusion. Therefore, while national regulations exhibit exclusive rights in biological and genetic materials as a property that can be transferred from one person to another, subject to certain restrictions, the intimate nature of genetic material begs the question of: To whom does such material truly belong?

\section{Redefining ownership for human biological material}

Redefining ownership in respect of materials obtained from human beings proves to be a formidable task as various aspects need to be taken into consideration. The question to be considered in redefining the concept of ownership within current legal understanding is described as follows: How do we develop a legal definition for ownership of HBM without making humanity appear as a commodity or without loss of human dignity? The legal definition of HBM and tissue as they stand is poorly defined, with variations occurring in different segments of legislation related to human bodily materials $s^{[4]}$ such as tissue, blood and blood products.

HBM removed from a human being either living or deceased should be entitled to the rights attributed to the body as a whole. Under these conditions I propose the following definition: A human biological sample shall include all cell types capable of being removed, by a trained professional, from a human body either intravenously and/or surgically without causing serious harm to a living individual provided informed 
consent has been granted prior to the removal. The cell types should be classified based on the cell potency, which is defined as a cell's ability to differentiate into one or more cell types within an organism ${ }^{[5]}$ from which these specific cell types form, that is, totipotency, pluripotency, multipotency, oligopotency and unipotency. In this way, all cell types are covered, from stem cells and blood and blood products to all forms of tissue which can be defined as a set of specialised cells that aggregate together to perform a specific function as a single unit. ${ }^{[6]}$

A totipotent cell is a stem cell capable of becoming any cell in the body. They are usually produced during the first few cell divisions of embryogenesis. It is from these stem cells that all other stems cell form. ${ }^{[5]}$ From these cells another set of stem cells are formed, known as pluripotent stem cells. These cells have the potential to differentiate into nearly all cells within the body but are sectionalised based on which of the three germ layers ${ }^{[5]}$ they enter into. Pluripotent stem cells have self-renewal properties as well as the potential to form all cell types of an adult organism. ${ }^{[7]}$

Multipotent stem cells are the next set of stem cells to form following a cascade of cell differentiation towards unipotent cells. These cells are capable of differentiation in various cell types but only with a certain family. ${ }^{[5]}$ They are therefore limited in the cell types they can become. For example, the bone marrow contains multipotent stem cells that give rise to all the cells of the blood but not to other types of cells. Adult haematopoeitic stem cells are multipotent. ${ }^{[8]}$

Oligopotent stem cells can differentiate into only a few cells within a cell type family, such as lymphoid or myeloid stem cells. The corneal epithelium is a squamous epithelium that is constantly renewing and is oligopotent. ${ }^{[8]}$

Lastly, unipotent cells are only able to produce one type of cell, their own, but still maintain the property of self-renewal, which distinguishes them from non-stem cells. Most epithelial tissues self-renew throughout adult life due to the presence of unipotent progenitor cells. ${ }^{[5,9]}$

Serious harm as adapted from the Unites States Code can be defined as any form of protracted or obvious loss of impairment of the function of a bodily member, organ or mental faculty (physical and/or mental disability), protracted or obvious disfigurement, extreme physical pain or risk of death that can occur during the extraction of cellular material from a living human host body. ${ }^{[10]}$ For example, the unintended awakening, of a patient during an extraction of cellular material by surgical procedures from their body, due to the administration of an insufficient amount of anaesthesia. The effect of such an event could result in the patient experiencing extreme pain as well as many other unintended consequences including the risk of death should the patient react in a manner that endangers his or her life due to the level of pain experienced.

\section{Genomics and gene patents}

Prior to the recent international ownership issues relating to genetic material such as that of patent laws, the common understanding was that such material was an open source with no one having exclusive rights to ownership over any piece of it. This allowed all countries to share their genetic resources freely. ${ }^{[1]}$ An example of open source in genetics is the Human Genome Project, an endeavour that required the collaboration of a number of different institutes sharing their information and data, therefore forcing each of them to decide on flexible research standards.

The realisation that both scientific and commercial gains can be made from human biological material has led to more stringent control over such materials nationally. Safrin ${ }^{[1]}$ refers to this as the legal enclosure of genetic material', which she attributes to two developments:
- the patenting of genetic material by predominantly developed countries

- a response to the privatisation of genes through the patent system and the extension of sovereignty over genetic resources by developing countries.

This patent action has led to a reaction by many in the developing world, implementing state sovereign rights or a form of national control over genetic resources. The interaction between the patent system and the sovereign-based system is described by Safrin as a 'corrosive interplay' eventually leading to a system she describes as 'hyperownership' of genetic material to the anticommons trap.

The anticommons is a concept introduced by Micheal Heller ${ }^{[12]}$ as 'the mirror image of common property' which plays in contrast to Hardin's Tragedy of the Commons. ${ }^{[13]}$ The philosophical idea expressed by Hardin sets forth the consequences of overuse of a natural resource, such that access to that resource becomes overrun. The anticommons however, proposes the opposite: a tragedy is likely to arise 'when these individuals or entities employ their rights to veto the use of a given resource and in so doing waste the resource by it's under consumption compared with the social optimum!. ${ }^{[12]}$

Hardin's Tragedy of the Commons represents over-consumption and exploitation of a resource without giving back to the entity from which it was taken. Heller's anticommons approach aims to identify the lack of willingness to allow others access and share in the benefits of that resource. From a genomics point of view this represents the effects of 'safari or helicopter' research, whereby genomic samples were collected from communities without proper consent or fair compensation, consequently leading to many nations seeking sovereign mandates over their genetic materials. In either case the action of both these groups incurs both social and economic repercussions. Additionally, the development of excessive sovereign control or ownership of genetic material is likely to lead to over-regulation, ${ }^{[11]}$ with bureaucratic red tape impeding important genetic research.

Although UNESCO's declaration states that the human genome in its natural state should not give rise to financial gain, ${ }^{[13]}$ it does not offer any protection over segments of the human genome. Many developed countries allow for genes that have been isolated, extracted and functions determined, to become a commodity, gain commercial value and allow for their patenting. ${ }^{[11,12]}$ In South Africa, current laws, such as the Biodiversity Act, ${ }^{[14]}$ restrict access to genetic material for the purpose of acquiring remuneration but the exclusion of human genetic material from the Act once again leaves a gap for exploitative means.

Globally, many developing countries such as Mexico, Brazil and India for example have in place regulatory guidelines ${ }^{[15]}$ that view human genetic material as a natural resource based on the concept of Genomic Sovereignty described as 'the capacity of a people, country or nation to own, to control both access and use of samples, data and knowledge emanating from genetic material[.' ${ }^{[16]}$ With the awakening of the wealth of genetic data available in their respective countries the so-called traditional distinctions in legal understanding between human and non-human genetic resources is slowly being eroded, with international bodies calling for amendments to the Convention of Biological Diversity to be made that govern access to human genetic material as well. ${ }^{[1]}$

\section{Patenting of DNA in biotechnology}

South Africa is fairly silent with regard to patenting any form of human genetic material and has in place laws, regulations and guidelines such 
as the Biodiversity Act as well as the guidelines for South Africa's bioprospecting, access and benefit-sharing regulatory framework issued by the Department of Environmental Affairs. ${ }^{[17]}$ Within these laws, issues surrounding patenting of biological resources are mentioned but indicate that these laws and guidelines exclude human genetic material. Nonetheless extrapolation of relevant information from such legal documents is still relevant in relation to human genetic material and could therefore be used as a stepping stone in an effort to set in motion regulatory legislature for human genetic resources.

\section{Patents Act No. 57 of 1978}

In 2005, section 2 of the Patents Act No. 57 of $1978^{[18]}$ was amended to include certain definitions as well as the requirement for an applicant of a patent to furnish information relating to any role played by an indigenous biological or genetic resource or traditional knowledge. Those who wish to file an application to the Patents Office using indigenous knowledge are obligated to disclose their source, therefore creating space to work out an equitable and fair compensation mechanism to the relevant community.

Section 25(1) of the Act states that a patent is granted for any new invention which involves an inventive step, and is capable of being used or applied in trade, industry or agriculture. For human genetic material patents, the definition itself poses major challenges.

\section{'Patent is granted for any new invention'}

A specific gene sequence or partial thereof is not novel. Such sequence data has existed prior to its scientific investigation and takes into account the Supreme Court ruling in Myraid Genetics ${ }^{[19]}$ that DNA isolated in its natural form cannot be patented or classified as a 'new invention'.

\section{'Which involves an inventive step'}

This statement implies that something new was created or an inventive step arose out of a process. For genetic information such as targeted gene isolation and expression, it is difficult to prove; as such biological processes already occur in nature, whether they are ancestral or mutant. In addition research that finds evidence of a gene or other genomic data that is or could be linked to a specific disease or disorder, constitutes more an event of discovery rather than an invention. Furthermore, the scientific theory applied to such a discovery is not eligible for patenting under the condition of an inventive step. ${ }^{[20]}$ This is justified by the need for scientific research to be continuously validated through reproducibility and proven robustness of a technique in order to either support or disprove a scientific theory.

\section{'Being used in trade, industry or agriculture'}

Trade can be taken to include all activities in society where services or commodities of any kind are exchanged for money or other goods of value. ${ }^{[19,22]}$ If an invention is to be patented it must be capable of being utilised or used in trade, industry or agriculture. Generally, South African law excludes discoveries, scientific theories and any human or animal treatment method including surgery, therapy or diagnostics as patentable inventions. ${ }^{[19]}$ 'Agriculture covers the science of farming, whether animals or crops, and in its broad sense also includes forestry, gardening and horticulture.[21] The wide range that an invention can cover makes it difficult to conceive its lack of utility, that is, not capable of being used or applied in trade, industry or agriculture, except for medical methods of treatment that are specifically excluded in the Patents Act. Section 25(1) of the Act ${ }^{[19]}$ does not define what a patent is but rather only provides clarification of what it cannot be.

\section{Legal conclusion}

Overall, the Patents Act leaves one with a feeling that information pertaining to human biological resources (that are relevant to genetics and other human associated studies) are overlooked and, upon review, one may question the apparent general lack of regulation of such material. However, the amendment requiring disclosure of the use of indigenous knowledge is noteworthy as this provides for a means to ensure fair compensation to the relevant communities through various benefit-sharing mechanisms. The question of ownership of human biological material undoubtedly raises the need for re-evaluation of how the concept of property is understood, interpreted and defined with regard to human genetic material. This in turn, should provide a link between open source data and biotechnology, as well as genomics as a whole with humanitarian objectives. Therefore, the potential to re-negotiate and re-design biotechnology with regard to human genetic material and information does exist.

\section{References}

1. Van der Walt AJ, Pienaar GJ. Chapter 4: Introduction to ownership. In: Introduction to the Law of Property. 5th ed. Cape Town: Juta, 2006:39-47.

2. Republic of South Africa. National Health ActNo. 63 of 2003, Regulation 180. Regulations regarding the general control of human bodies, tissue, blood and blood products and gametes. Government Notice R180. Government Gazette No. 350992012.

3. Republic of South Africa. National Health Act No. 63. Government Gazette 2003.

4. Mahomed S, Nöthling-Slabbert M, Pepper MS. The legal position of the classification of human tissue in South Africa: Can tissues be owned? South African Journal of Bioethics and Law 2013;6(1):16-20. [http://dx.doi.org/10.7796/SAJBL.258]

5. Hima BA, Srilatha B. Potency of various types of stem cells and their transplantation.J Stem Cell Res Ther 2011;1(115):1-6. [http://dx.doi.org/10.4172/2157-7633.1000115]

6. Defining Tissue: http://www.oxforddictionaries.com/definition/english/tissue (accessed 25 June 2014).

7. Horie M, Ito A, Kawabe $Y$, Kamihira M. A genetically engineered STO feeder system expressing E-Cadherin and leukemia inhibitory factor for mouse pluripotent stem cell culture. J Bioprocess Biotech 2011;S3(001). [http://dx.doi. org/10.4172/2155-9821.S3-001]

8. Weissman IL. Stem cells: Units of development, units of regeneration and units of evolution. Cell 2000;100(1):157-168. [http://dx.doi.org/10.1016/S0092-8674(00)81692-X]

9. Murnaghan I. Explore Stem Cells-Unipotent Stem cells: http://www. explorestemcells.co.uk/unipotentstemcells.html (accessed 12 August 2014).

10. Unites States of America. Office of the Law Revision Council: Unites States Code. Title 18-Crimes and criminal procedure, Part I, Chapter 109A, \$2246(4). Serious bodily injury. http://uscode.house.gov/view.xhtml?req=\%28title:18\%20 section:2246\%20edition:prelim\%29 (accessed 25 June 2014).

11. Safrin S. Hyperownership in a time of biotechnological promise: The international conflict to control the building blocks of life. Am J Int Law 2004;98(4):641-685.

12. Heller MA. The tragedy of the anticommons: Property in the transition from Marx to markets. Harvard Law Review 1998;111(3):621-622.

13. UNESCO: Universal Declaration on Bioethics and Human Rights. http://portal. unseco.org/en/ev.php-URL_ID=31058andURL_DO_TOPICandURL_section=201. html. (accessed 9 March 2012).

14. Republic of South Africa. Biodiversity Act No. 10. Government Gazette 2004.

15. Sequin B, Hardy BJ, Singer PA, Daar AS. Genomic medicine and developing countries: Creating a room of their own. Nat Rev Genet 2008;9(6):487-493.

16. Slabbert MN, Pepper M. A room of our own? Legal lacunae regarding genomic sovereignty in South Africa. Journal of Contemporary South African Roman-Dutch Law 2010;73:432-450.

17. Republic of South Africa. Department of Environmental Affairs. South African Bioprospecting access and benefit-sharing regulatory framework: Guidelines for providers, users and regulators. Pretoria 2012. https:/www.environment.gov.za/sites/default/files/legislations/ bioprospecting_regulatory_framework_guideline.pdf (accessed 25 September 2013).

8. Republic of South Africa, Patents Act No. 57. Government Gazette 1978.

19. Association for Molecular Pathology et al, Petitioners V Myraid Genetics, Inc, et al. Supreme Court Opinion. Pretoria June 2013. http://www.supremecourt.gov/ opinions/12pdf/12-398_1b7d.pdf (accessed 25 September 2013).

20. World Health Organization. Human Genetics Programme. Genetics, Genomics and the patenting of DNA: Review of potential health implications in developing countries. Geneva: World Health Organization, 2005. http://www.who.int/ genomics/FullReport.pdf. (accessed 25 September 2013).

21. Mukuka GS. Chapter 5: Intellectual property laws in South Africa. In: Reap what you have not sown, Indigenous Knowledge Systems and Intellectual Property Laws in South Africa. Pretoria: Pretoria University Law Press, 2010:137-143. http:// www.pulp.up.ac.za/pdf/2010_16/2010_16.pdf (accessed 25 September 2013). 